\title{
Arginase Enzyme Inhibition and with Subsequent Atheroprotection of Butanol Fraction of Rivea ornata in Lipid Emulsion Induced Atherosclerosis in Rats
}

\author{
Mallela Vijaya Jyothi' ${ }^{1}$, Nayakanti Devanna ${ }^{2}$, Akkiraju Sudheer,* \\ 'Department of Pharmaceutical Chemistry, Raghavendra Institute of Pharmaceutical Education and Research, Ananthapuramu, Andhra Pradesh, INDIA. \\ ${ }^{2}$ Oil Technological and Pharmaceutical Research Institute, JNTUA College of Engineering, Ananthapuramu, Andhra Pradesh, INDIA. \\ ${ }^{3}$ Department of Pharmaceutical Sciences, JNTUA, Ananthapuramu, Andhra Pradesh, INDIA.
}

\begin{abstract}
Objectives: Atherosclerosis is caused by vascular inflammation and oxidative stress. Pro-atherogenic effect of hypercholesterolemia caused by impairment of nitric oxide generation due to activated arginase. The current study was wanted to explore the atheroprotective effect of polyphenolic fraction of Rivea ornata by using lipid emulsion induced atherosclerosis in rat model. Materials and Methods: The study carried out by studying atherogenic markers in the serum (lipid profiles, C-reactive protein), vascular tissue (myeloperoxidase, arginase, hydroxyproline, lipid peroxidation) and atheroprotective factors in the serum (paraoxonase, nitric oxide,) and in the vascular tissue (thiol levels, endogenous antioxidants) after feeding the rats with lipid emulsion for 12 weeks. Results: Treatment of polyphenolic rich butanol fraction is able to correct the imbalance of atherogenic and antiatherogenic factors induced by lipid emulsion feeding. Butanol fraction at the dose of $400 \mathrm{mg} / \mathrm{kg}$ significantly increases HDL, paraoxonase, nitric oxide, tissue thiol levels, endogenous antioxidants and decreases TG, TC, VLDL,
\end{abstract}

LDL myeloperoxidase, arginase, hydroxyproline, lipid peroxidation. And atheroprotection reflected in histopathology studies also. Lipid emulsion associated foam cells formation is inhibited by butanol fraction. Conclusion: This is all due to presence of gallic acid in polyphenol rich butanol fraction is responsible for the underlying mechanism of atheroprotection.

Key words: Butanol fraction, Cardiac rick factors, HPLC analysis, Inflammation markers, Lipid emulsion induced atherosclerosis, Lipid profiles.

\section{Correspondence}

Mr. Akkiraju Sudheer,

Research Scholar, Department of Pharmaceutical sciences, JNTUA Ananthapuramu-515002, Andhra Pradesh, INDIA.

Email id: sudeerlegend@gmail.com;

ORCID: 0000-0003-4865-4161

DOI: 10.5530/ijpi.2021.2.32

\section{INTRODUCTION}

Atherosclerosis is characterised by deposition of atherosclerotic plaques, composed of cholesterol, calcium, fibrotic tissue in the lumen of medium and large sized arteries leads to reduction of blood flow at sufficient level. ${ }^{1}$ The patents don't exhibit any sign of ischemia even lumen obstruction reached to $70 \%$, after that patient getting experience the symptoms of angina and further myocardial infraction. ${ }^{2}$ Ischemic heart disease and stroke are consequence of atherosclerosis and are responsible for $>80 \%$ total cardiovascular death (CVD). Cardiovascular diseases (CVDs) have now become the leading cause of mortality in India, a quarter of all mortality is attributable to CVD. As per WHO, 23.6 million people are expected to die from CVD by 2030 . People with presence of one or more risk factors such as hypertension, diabetes, hyperlipidaemia, obesity are prone for development of atherosclerosis. ${ }^{3}$ Molecular bases for atherosclerosis include series of events includes endothelial damage, deficiency of vasodilator nitric oxide, intraluminal deposition of oxidized LDL, infiltration of monocytes, secretion of inflammatory cytokines, deposition of lipid loaded macrophage causes of blocking of lumen of arterial wall partially or completely. ${ }^{4}$ So many researchers are trying to find the potential targets which influence the progress of atherosclerosis. One of such identified targets is arginase pathway. Arginase involved in metabolism of L-arginine in to ornithine and urea, due to which decline the levels of arginine, is a precursor of nitric oxide in the vascular endothelial cells. As a result, causes vascular endothelial dysfunction, is the step of initiation of atherosclerosis. In one recent study arginase knockout rats observed improved nitric oxide signalling and also vascular endothelial function. ${ }^{5}$ Apart from this, various clinical and non-clinical studies proven that arginase pathway is involved in endothelial dysfunction and as associated problems such as atherosclerosis, hypoxia, diabetes and hypertension. ${ }^{6}$ Arginaseenzymeinhibitorsareattractivetargetsfortreatment of atherosclerosis, in parallel polyphenolic compounds are known reported as arginase enzyme inhibitors. ${ }^{7}$ Basing on our preliminary studies of butanol fraction of Rivea ornata respective to phenolic and flavonoid content we planned for anti-atherosclerotic effect of Rivea ornata. Rivea ornata is a climber with cylindrical stem, broader leaves, white silky flowered and smooth surface sub globose brown-coloured fruits. Literature mentions its traditional importance in treating disorder of gallbladder, disease of heart, bronchitis, and fatigue. In the Konkan, its juice is used to treat piles. ${ }^{8}$ In Sri Lanka fresh leaves used in diabetes, bergenin is a polyphenolic compound identified in that plant, aerial parts of this plant have antiinflammatory effect, reported as analgesic and antipyretic and also is a one of the components of sidda formulation named Maavilingapattai chooranam used as hepatoprotective agent. ${ }^{9}$

\section{MATERIALS AND METHODS}

\section{Collection and identification of the plant material}

Fresh leaves collected from flowering plant of Rivea ornata, were collected from Tirumala hills during between December to January and dried under shade. The plant was authenticated by Prof. K. Madhava Chetty, 
Taxonomist, and a voucher specimen (voucher number: 0913) has been stored at S.V. University (Botany department) Tirupati, (A.P, India).

\section{Extract preparation, phytochemical screening}

$1 \mathrm{~kg}$ of dried leaves powder was macerated with 3 litters of ethanol (99\%) for 1 week. Filtrate of the extract was concentrating under reduced pressure using rota evaporator. Crude semisolid extract was dissolved in hot water and further fractionated with solvents from low polar to high polar such as $n$-hexane $(3 \times 200 \mathrm{ml})$, ethyl acetate $(3 \times 200 \mathrm{ml})$, butanol $(3 \times 200 \mathrm{ml})$ and finally remaining aqueous fraction. Each fraction was evaporating to dryness using rota evaporate to get the concentrate form. Phytochemical investigation was determined in crude ethanol extract and its fractions as per established methods. ${ }^{10}$

\section{Estimation of Total phenolic and flavonoid content}

Phenolic and flavonoid contents of crude ethanol extracts and its fraction (n-hexane, ethyl acetate, butanol and aqueous fraction) was estimated by Folin- Ciocalteu reagent and aluminium chloride reagent. For phenolic content estimation, the $(0.5 \mathrm{~mL})$ diluted extracts and its fractions at concentration of $1 \mathrm{mg} / \mathrm{mL}$ and varying concentration of gallic acid $(20 \mu \mathrm{g}, 40 \mu \mathrm{g}, 60 \mu \mathrm{g}, 80 \mu \mathrm{g}$ and $100 \mu \mathrm{g} / \mathrm{mL}$ ) mixed with $5 \mathrm{~mL}$ of FolinCiocalteu's reagent $(10 \% \mathrm{v} / \mathrm{v})$ and shaken it well. Add $4 \mathrm{~mL}$ of $\mathrm{Na}_{2} \mathrm{CO}_{3}$ $(7 \% \mathrm{w} / \mathrm{v})$ solution after $5 \mathrm{~min}$ to the above solution. Incubate the solution for $90 \mathrm{~min}$ at room temperature and absorbance was determined at $750 \mathrm{~nm}$. For flavonoid content, the $1 \mathrm{~mL}$ of extracts (crude ethanol extracts and its fractions-n-hexane, ethyl acetate, butanol and aqueous) and standard solutions of quercetin at concentration of 20,40, 60, 80 and $100 \mu \mathrm{g} / \mathrm{mL}$ were mixed with $2.5 \mathrm{~mL}$ of freshly prepared $\mathrm{AlCl}_{3}(10 \% \mathrm{w} / \mathrm{v})$ after $5 \mathrm{~min}$ and add $1 \mathrm{M} \mathrm{NaOH}$ of about $2 \mathrm{~mL}$ and total volume make up to $10 \mathrm{~mL}$ with $\mathrm{DW}$. The whole solution was mixed up and absorbance was measured against blank at $510 \mathrm{~nm}$ after 30 mins incubation. The contents were expressed as milligrams of gallic acid equivalents (GAE) and Quercetin equivalents (QE) per g dry weight of extract. ${ }^{11}$

\section{Column chromatography of butanol fraction}

The butanol fraction was subjected to Silica gel column chromatography for the separation of polyphenolic compounds. Initially methanol solubilized butanol fraction $(1.5 \mathrm{~g})$ was mixed with silica gel in motor by trituration with pestle. Fraction coated silica gel placed on the top of silica gel (60-120 mesh) packed chromatography column $(75 \mathrm{~cm} \times 3.5 \mathrm{~cm})$. The column was serially eluted with hexane, hexane and ethyl acetate (1:1 ration) and ethyl acetate. Total 40 sub-fractions of $150 \mathrm{~mL}$ were collected and concentrated using rotary evaporator at $45^{\circ} \mathrm{C}$ under reduced pressure, then mixed on the basis of their TLC matching with standard flavonoid (quercetin). ${ }^{12}$

\section{Identification of Flavonoids by TLC}

n-Butanol fraction was tested in TLC for presence of flavonoids. The TLC pre-coated silica gel $60 \mathrm{GF}_{254}$ plates were developed using a flat bottom chamber which was pre-saturated with the mobile phase for $30 \mathrm{~min}$. In the TLC method, n-hexane and ethyl acetate (1:1) was used as optimized mobile phase in order to effective separation. After development of TLC chromatogram of butanol extract and standard flavonoid, plates had been removed and dried, the spots were visualized by kept in and iodine chamber. Fraction which are matched with standard are pooled together and further they are analyzed by HPLC for polyphenolic profiling. ${ }^{13}$

\section{HPLC analysis of butanol fraction}

HPLC analysis of polyphenolic compounds of butanol fraction was determined based on retention time of eluted compounds.
HPLC chromatography conditions

System: Agilent LC1200

Software: EZ Chrome Elite

Column: $\mathrm{C}_{18}$ Normal-phase analytical column $(250 \times 4.6 \mathrm{~mm})$

Solvent system: Binary gradient mode, (Acetonitrile: water -65:35)

Pump: Pneumatic pump

Injection volume: Injection volume $20 \mu \mathrm{L}$

Solvent flow rate: Total flow $1 \mathrm{~mL} / \mathrm{min}$, column oven temperature was $25^{\circ} \mathrm{C}$

Detection wavelength: $230 \mathrm{~nm}$.

Detector: Diode Array Detector (DAD)

Polyphenolic matched TLC butanol fraction was dissolved in methanol and further filtered with Millipore filters before injection. Standard polyphenolic compounds were also processed same as that of butanol fraction. Standards used in this experiment are quercetin, gallic acid, naringin, ellagic acid for qualitative evaluation of phenolic compounds. ${ }^{14}$

\section{Animals}

Male wistar rats (160-200 g body weight) were used for this study. They were housed at ambient temperature $\left(24 \pm 2^{\circ} \mathrm{C}\right)$, relative humidity $(45 \pm 5 \%)$ and $12 \mathrm{~h} / 12 \mathrm{~h}$ light dark cycle. Animals had free access to pellet and drinking water was given ad libitum. The Institutional Animal Ethics Committee (878/ac/05/CPCSEA/005/2016) approved the experimental protocol at Department of Pharmacology, Raghavendra Institute of Pharmaceutical Education and Research, Anantapuramu, Andhra Pradesh, India in accordance with the guidelines of Committee for the Purpose of Control and Supervision of Experiments on Animals (CPCSEA), Ministry of Social Justice and Empowerment, Government of India, New Delhi.

\section{Acute toxicity studies}

It was performed as per specification of OECD, 423 protocol. No toxic symptoms or mortality was observed until the 14 days of the period with butanol extract of Rivea ornata $2000 \mathrm{mg} / \mathrm{kg}$ bw. Hence, further experimental dose was selected as one tenth and one fifth of the $\mathrm{LD}_{50}$ dose that is $200 \mathrm{mg} / \mathrm{kg}$ and $400 \mathrm{mg} / \mathrm{kg}{ }^{15}$

\section{Lipid emulsion induced atherosclerosis model}

To induce atherosclerosis in wistar rats, feed orally with freshly prepared lipid emulsion daily for the period of 12 weeks continuously at the dose of $1.5 \mathrm{ml} / \mathrm{kg}{ }^{16}$

Composition of lipid emulsion

\begin{tabular}{cc}
\hline Content & Quantity \\
\hline Cholesterol & $45 \mathrm{mg} / \mathrm{mL}$ \\
Lard & $15 \mathrm{mg} / \mathrm{mL}$ \\
Sodium cholate & $7.5 \mathrm{mg} / \mathrm{mL}$ \\
Propylthiouracil & $3 \mathrm{mg} / \mathrm{mL}$ \\
Sugar & $75 \mathrm{mg} / \mathrm{mL}$ \\
Vitamin $\mathrm{D}_{3}$ & $100000 \mathrm{IU} / \mathrm{kg}$ \\
\hline
\end{tabular}

\section{Experimental design}

A total of 30 male wistar rats are allocated in to five groups and six animals in each. All the animals were treated 12 weeks' period. 


\begin{tabular}{ccc}
\hline Groups & Type of treatment & Diet provided daily \\
\hline I & Normal control & Normal pellet diet \\
II & Vehicle control, $22 \mathrm{ml} / \mathrm{kg}$, oral & Lipid emulsion \\
III & Standard - Atorvastatin, $10 \mathrm{mg} / \mathrm{kg}$ oral & Lipid emulsion \\
IV & Butanol fraction of Rivea ornata, $200 \mathrm{mg} / \mathrm{kg}$ & Lipid emulsion \\
& oral (BFRO) & \\
V & Butanol fraction of Rivea ornata, $400 \mathrm{mg} / \mathrm{kg}$ & Lipid emulsion \\
& oral (BFRO) & \\
\hline
\end{tabular}

\section{Estimation of serum parameters}

Blood samples collected via puncturing the retrorbitol plexus under anaesthesia and allowed to clot for $10 \mathrm{mins}$ at room temperature. It was centrifuged at $3000 \mathrm{rpm}$ for $15 \mathrm{~min}$. Separated serum was stored at $4^{\circ} \mathrm{C}$ until used. This serum was used for the estimation of following biochemical parameter such as triglyceride (TG), total cholesterol (TC), high density lipoprotein (HDL), very low-density lipoprotein (VLDL), low density lipoprotein (LDL), lactate dehydrogenase (LDH), creatin kinase-MB (MB) and c-reactive protein (CRP). ${ }^{17}$

\section{Paraoxonase-1 (PON-1) activity}

The arylesterase activity in the serum was determined by the procedure described by Gan et al., (1991). Briefly, the reaction was carried out in a $1 \mathrm{ml}$ spectrophotometric cuvette. The reaction mixture contained Tris$\mathrm{HCl}$ buffer $\mathrm{pH} 8,200 \mathrm{mM} \mathrm{CaCl}_{2}$, and $2 \mathrm{mM}$ phenyl acetate as substrate. The reaction was initiated by the addition of $7 \mathrm{ml}$ of serum. The change in optical density at $270 \mathrm{~nm}$ was recorded for every $20 \mathrm{sec}$ up to $1 \mathrm{~min}$ Blanks without the serum were used to subtract spontaneous hydrolysis of phenyl acetate. One unit of enzymes activity was defined as that amount of enzyme that release $1 \mathrm{~m} \mathrm{~mol}$ of phenol per min under the assay conditions. Molar extinction coefficient of $1310 \mathrm{M}^{-1} \mathrm{~cm}^{-1}$ was used to calculate the product formed. The results are expressed as units per $\mathrm{ml}$ serum. $^{18}$

\section{Estimation of tissue parameters}

The animals were euthanasiously sacrificed after blood collection; thoracic aorta was quickly transferred to chilled ice-cold phosphate buffered saline $(10 \mathrm{mM}, \mathrm{pH} 7.4)$. The tissues were then minced and homogenized to a concentration of $10 \% \mathrm{w} / \mathrm{v}$. The homogenate was centrifuged at 7,000 rpm at $0^{\circ} \mathrm{C}$ for $25 \mathrm{~min}$ using Remi C-24 high speed cooling centrifuge. The tissue homogenate used for estimation of markers of oxidative stress such as reduced glutathione, catalase, superoxide dismutase and products of lipid peroxidation. ${ }^{19}$

\section{Determination of total thiol levels}

Total thiol levels were determined via a spectrophotometric method using Ellman's reagent. DTNB (2,2'-dinitro5,5'-dithiodibenzoic acid) reacts with the $\mathrm{SH}$ group found in thiol molecules.

The product formed is yellow in huewith a peak absorbance at $412 \mathrm{~nm}$. Briefly, $50 \mu \mathrm{l}$ of supernatant was added to $1 \mathrm{ml}$ Tris-EDTA (ethylenediaminetetraacetic acid) buff er $(\mathrm{pH}=8.6)$ and the absorbance was read at $412 \mathrm{~nm}$ against Tris EDTA buffer alone (A1). Then, $20 \mu \mathrm{l}$ of $10 \mathrm{mM}$ solution of DTNB (10 mM in methanol) was mixed with heart or aorta homogenate and the absorbance was read again (A2). The absorbance of DTNB reagent was also read as blank (B). Total thiol was expressed as $\mathrm{mM}$ per gram of tissue. ${ }^{20}$

\section{Measurement of arginase activity}

Aorta tissue homogenate $(50 \mathrm{~mL})$ was added into $75 \mathrm{~mL}$ of Tris $\mathrm{HCl}$ $(50 \mathrm{mmol} / \mathrm{L}, \mathrm{pH} 7.5)$ containing $10 \mathrm{mmol} / \mathrm{L} \mathrm{MnCl}_{2}$. Heating the lysate at $55-60^{\circ} \mathrm{C}$ for $10 \mathrm{~min}$ activated arginase. The hydrolysis reaction of L-arginine by arginase was performed by incubating the mixture containing activated arginase with $50 \mu \mathrm{L}$ of L-arginine $(0.5 \mathrm{~mol} / \mathrm{L}$, $\mathrm{pH} 9.7$ ) at $37^{\circ} \mathrm{C}$ for $1 \mathrm{hr}$ and was stopped by adding $400 \mathrm{~mL}$ of the acid solution mixture $\left(\mathrm{H}_{2} \mathrm{SO}_{4}: \mathrm{H}_{3} \mathrm{PO}_{4}: \mathrm{H}_{2} \mathrm{O}=1: 3: 7\right)$. For calorimetric determination of urea, $\alpha$-isonitrosopropiophenone $(25 \mu \mathrm{L}, 9 \%$ in absolute ethanol) was then added and the mixture was heated at $100^{\circ} \mathrm{C}$ for $45 \mathrm{~min}$. After placing the sample in the dark for $10 \mathrm{~min}$ at room temperature, the urea concentration was determined spectrophotometrically, with the absorbance at $550 \mathrm{~nm}$ being measured with a microplate reader. The amount of urea produced, after normalization with protein, was used as an index for arginase activity. ${ }^{21}$

\section{Estimation of nitric oxide}

Nitric oxide (NO) concentration in the samples was assayed by the colorimetric method by using Griess reagent. Equal volume of supernatant was rapidly mixed with Griess reagent (v/v) and kept in the dark for $20 \mathrm{~min}$. The absorbance was measured at $550 \mathrm{~nm}$ and the quantification was calculated from a standard curve pre-established with different concentration of sodium nitrite..$^{22}$

\section{Estimation of myeloperoxidase in cardiac tissue}

The myeloperoxidase (MPO) activity was assessed as previously described by method. $10 \% \mathrm{w} / \mathrm{v}$ cardiac tissue homogenate was prepared by homogenized buffer ( $0.5 \%$ of hexadecyl trimethyl ammonium bromide in $50 \mathrm{mM}$ phosphate buffer, $\mathrm{pH}$ 6.0). Then the homogenate undergone three cycles of freezing and thawing and followed by centrifugation at $4^{\circ} \mathrm{C}$ for $20 \mathrm{~min}$. Supernatant $(0.1 \mathrm{ml})$ of the homogenate was mixed with $2.9 \mathrm{ml}$ of reaction agent (combination of $50 \mathrm{mM}$ phosphate buffer $(4.9 \mathrm{ml} ; \mathrm{pH}$ $6.0), 0.167 \mathrm{mg} / \mathrm{ml}$ of $\mathrm{O}$-dianisidine hydrochloride and hydrogen peroxide $(0.0005 \%)$. With UV spectrophotometer change in the absorbance (5 min) was recorded at $460 \mathrm{~nm}$. The MPO activity was calculated using the following formula. MPO activity $(\mathrm{U} / \mathrm{g})=\mathrm{X} /$ weight of the piece of tissue taken, where $\mathrm{X}=10 \times$ change in absorbance per min/volume of supernatant taken in the final concentration. ${ }^{23}$

\section{Estimation of Hydroxyproline Content in cardiac tissue}

A colorimetric assay as described by Reddy and Enwemeka was used to estimate hydroxyproline in cardiac tissue sample. Briefly, $100 \mathrm{mg}$ dry tissue sample was digested in $2 \mathrm{ml}$ of $\mathrm{HCl} 6 \mathrm{M}$ by keeping at boiling water bath for $3 \mathrm{~h}$. Tissue hydrolysate was added $\mathrm{NaOH}$ to adjust the $\mathrm{pH}$ to 6.5 - 7.0. Then, $1.0 \mathrm{~mL}$ of chloramine $\mathrm{T}$ solution $(0.05 \mathrm{M} / \mathrm{L})$ was added to tissue hydrolysate solutions $(1 \mathrm{~mL})$ and allowed the mixture aside for $20 \mathrm{~min}$ at room temperature. To this, added $1 \mathrm{~mL}$ of $20 \%$ p-dimethyl benzaldehyde (Ehrlichs reagent) solution, again the solution was placed at $60^{\circ} \mathrm{C}$ for $20 \mathrm{~min}$. Absorbance of final solution was read at $550 \mathrm{~nm} \cdot{ }^{24}$

\section{Histopathology}

Immediately after scarification, hearts were removed and placed in $10 \%$ buffered formalin, embedded in paraffin, cut to $5 \mu \mathrm{m}$ section for slides and stained with hematoxylin and eosin. The slides were examined with a Magnus microscope. The sections were observed under 10X and 40X magnifications

\section{Statistical analysis}

All the data are expressed as mean \pm SEM. Statistical significance between more than two groups was tested using one-way ANOVA followed by the Bonferroni multiple comparisons test as appropriate using computer based fitting program (Prism, Graph pad). Differences were considered to be statistically significant when $P<0.05$ 


\section{RESULTS}

Result of qualitative analysis and its contents of (phenolic and flavonoid) in various extracts/fractions of Rivea ornata

From the observation of qualitative test, we observed that butanol fraction gets positive evidence of flavonoids by all flavonoid assessment tests. Phenolic and flavonoid content were calculated from calibration curve of gallic acid and quercetin respectively. Butanol fraction has highest contents $(82.4 \pm 4.61 \mathrm{mg}$ of $\mathrm{GAE} / \mathrm{g}, 105 \pm 4.09 \mathrm{mg}$ of quercetin/g) compared to crude ethanol and its other fractions such as n-hexane, ethyl acetate and aqueous fraction. Results are shown in Table 1.

Test 1. Shinoda test (Deep red colour); Test 2. Lead acetate test (Yellow colour ppt); Test 3. Pews tests (Red colour to cherry red colour); Test 4. NaOH (Yellow colour); TPC (Total phenolic content -mg of gallic acid equivalent/g); TFC (Total flavonoid content -mg of quercetin equivalent/g). All values are expressed as the mean \pm SD of three replicate. Statistical values were consider significant when $\mathrm{p}$ value lower than 0.05 .

\section{HPLC Profile of collected fractions}

TLC matched butanol fractions were observed peaks identical with retention time of standard phenolic compounds in the HLPC chromatogram. Theretentiontimeoffractionswerematchedwithgallicacid retention time, it is known phenolic compound having broad biological activity. This data supports the presence of gallic acid type polyphenolic compounds. Results are shown in Figure 1 and 2.

Table 1: Qualitative results of flavonoids in Rivea ornata plant extracts.

\begin{tabular}{ccccccc}
\hline Extract & Test & Test & Test & Test & TPC & TFC \\
& 1 & 2 & 3 & 4 & & \\
\hline $\begin{array}{c}\text { Crude } \\
\text { ethanol }\end{array}$ & + & + & + & + & $56.9 \pm 4.30$ & $55.1 \pm 2.79$ \\
extract & & & & & & \\
n-Hexane & - & - & - & - & $6.39 \pm 1.38^{* * *}$ & $16.7 \pm$ \\
fraction & & & & & & $0.351^{* * *}$ \\
$\begin{array}{c}\text { Ethyl acetate } \\
\text { fraction }\end{array}$ & - & + & + & + & $64.2 \pm 1.56$ & $77.5 \pm 6.20^{*}$ \\
$\begin{array}{l}\text { Butanol } \\
\text { fraction }\end{array}$ & + & + & + & + & $82.4 \pm 4.61^{* *}$ & $105 \pm 4.09^{* * *}$ \\
Aqueous & - & - & - & - & $18.1 \pm 3.52^{* * *}$ & $27.7 \pm 4.10^{* *}$ \\
fraction & & & & & & \\
\hline
\end{tabular}

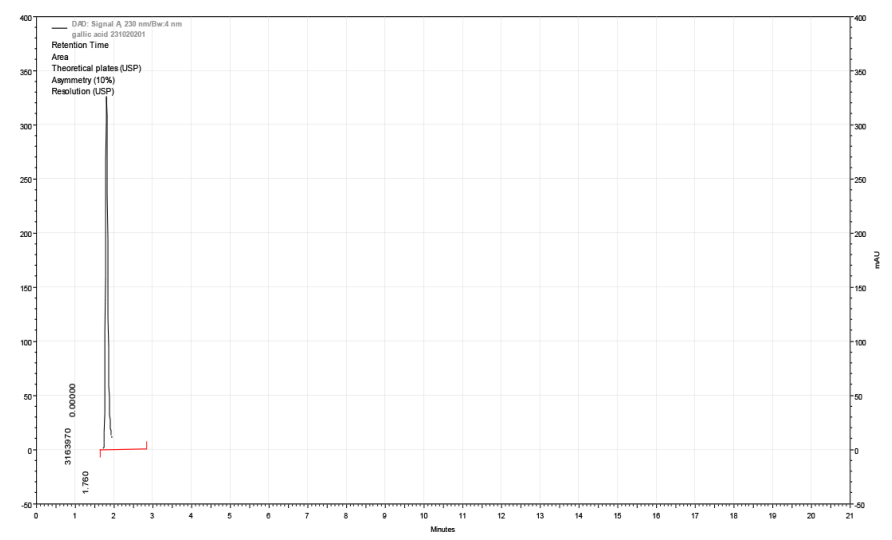

Figure 1: HPLC chromatogram of Gallic acid (standard Phenolic compound).

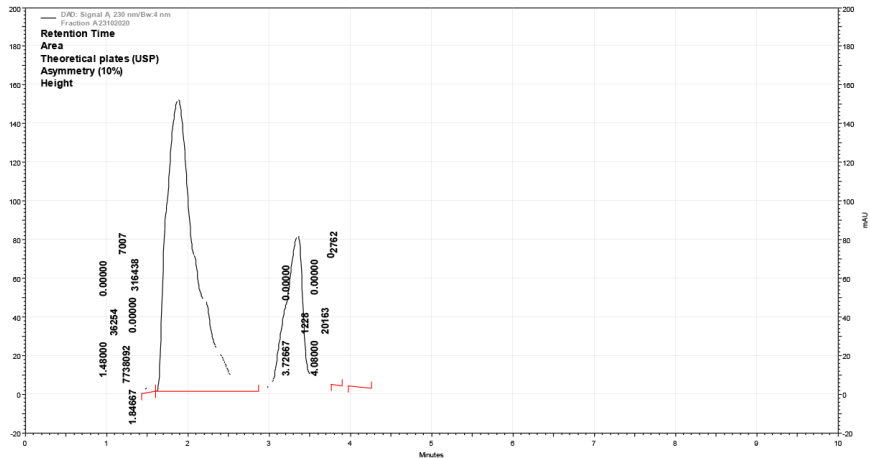

Figure 2: HPLC chromatogram of butanol fraction.

Table 2: Observation of body weight changes, atherogenic index and percentage protection.

\begin{tabular}{|c|c|c|c|c|c|}
\hline $\begin{array}{l}\text { 음 } \\
\text { 눈 }\end{array}$ & 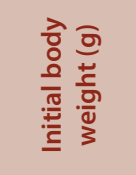 & 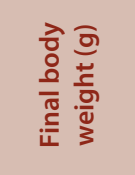 & 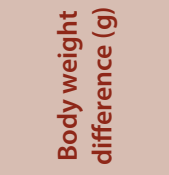 & 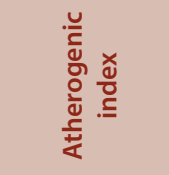 & 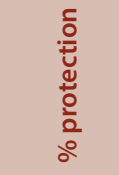 \\
\hline $\mathrm{I}$ & $198 \pm 3.58$ & $310 \pm 10.7$ & $153 \pm 3.58$ & $2.70 \pm 0.127$ & \\
\hline II & $203 \pm 10.3$ & $435 \pm 9.05$ & $252 \pm 9.05^{\star * *}$ & $22.9 \pm 1.53^{\star * *}$ & \\
\hline III & $230 \pm 10.5$ & $444 \pm 14.0$ & $214 \pm 4.50^{* *}$ & $4.77 \pm 0.487^{* * *}$ & $79.2 \pm 1.48$ \\
\hline IV & $198 \pm 6.18$ & $428 \pm 9.27$ & $230 \pm 5.83 \mathrm{NS}$ & $21.2 \pm 2.91$ & $16.9 \pm 6.20$ \\
\hline $\mathrm{V}$ & $210 \pm 6.92$ & $423 \pm 9.41$ & $213 \pm 5.97^{* *}$ & $12.7 \pm 1.11^{* *}$ & $43.9 \pm 4.69$ \\
\hline
\end{tabular}

\section{Effect of biactive butanol fraction on physiological changes}

After 12 weeks of lipid emulsion administration there is significant ( $* * *$ $p<0.001)$ increase in body weights of group II (Lipid emulsion group) animals compared to normal diet received animals. Whereas butanol fraction of Rivea ornata at the higher dose $(400 \mathrm{mg} / \mathrm{kg})$ is efficiently $\left({ }^{* *} p<0.01\right)$ control the weight gain induced by lipid emulsion. But body weight changes are not significant in lower dose of test fraction. Lipid emulsion alone has increase the atherogenic index significantly ( $* * *$ $p<0.001)$ compared to normal pellet diet. Atorvastatin and higher dose of butanol fraction reduces atherogenic index significantly $\left({ }^{* *} p<0.001\right.$ and $\left.{ }^{* *} p<0.01\right)$ ). And also exhibit higher percentage of atheroprotection from higher dose of butanol fraction. Results are represented in Table 2.

The data represented as mean \pm SEM for six rats, Values were considered significant when $\mathrm{p}$ value less than 0.05 . Significant values were represented as follows such as ${ }^{\star} p<0.05,{ }^{* *} p<0.01,{ }^{* * *} p<0.001$. Statistical values of all groups were compared with group II.

\section{Effect of butanol fraction on serum lipid parameters}

Serum lipid profiles of animals of all groups were determinate every 21 days up to 84 days. Base line lipid profiles of all groups of animals were not significant at 0 week. Lipid emulsion alone start producing hyperlipidaemic state after 21 days and it is continued up to 84 days compared to control animals received normal pellet diet. It is evident by significant $\left.{ }^{* * *} p<0.001\right)$ increase in bad lipids such as TG, TC, LDL, VLDL and decrease in good lipid such as HDL was observed with lipid emulsion. Chronic administration of butanol fraction start showing antihyperlipidemic effect significantly $\left({ }^{*} p<0.05\right)$ after 21 days especially at dose of $400 \mathrm{mg} / \mathrm{kg}$ but not lower dose and continued up to 84 days. It is evident by significant decrease in TG, TC, LDL, VLDL and decrease in HDL. Results are shown in Table 3. 
Table 3: Lipid profile changes induced by lipid emulsion and its effects by butanol fraction of Rivea ornate.

\begin{tabular}{|c|c|c|c|c|c|c|}
\hline Test & Day & Group I & Group II & Group III & Group IV & Group V \\
\hline \multirow[t]{4}{*}{$\mathrm{TC}(\mathrm{mg} / \mathrm{dL})$} & 0 & $41.3 \pm 2.50$ & $42.8 \pm 2.12$ & $43.0 \pm 2.26$ & $47.0 \pm 2.05$ & $46.3 \pm 3.36$ \\
\hline & 21 & $47.8 \pm 2.84$ & $80.1 \pm 5.87^{\star \star \star}$ & $58.3 \pm 0.910^{\star *}$ & $90.7 \pm 2.45$ & $70.2 \pm 4.47$ \\
\hline & 63 & $65.3 \pm 1.57$ & $157 \pm 7.45^{\star * *}$ & $76.9 \pm 1.71^{\star * *}$ & $166 \pm 5.36$ & $135 \pm 3.78^{*}$ \\
\hline & 84 & $71.6 \pm 2.29$ & $177 \pm 8.71^{\star * *}$ & $107 \pm 7.46^{* * *}$ & $176 \pm 5.42$ & $146 \pm 6.92^{*}$ \\
\hline \multirow[t]{4}{*}{$\mathrm{TG}(\mathrm{mg} / \mathrm{dL})$} & 0 & $38.3 \pm 2.09$ & $40.0 \pm 2.35$ & $39.8 \pm 1.71$ & $42.1 \pm 1.68$ & $43.7 \pm 1.56$ \\
\hline & 42 & $41.1 \pm 2.10$ & $71.0 \pm 2.21^{* * *}$ & $49.6 \pm 2.99^{\star * *}$ & $75.3 \pm 2.62$ & $59.2 \pm 1.80^{*}$ \\
\hline & 63 & $40.7 \pm 1.83$ & $88.5 \pm 1.93^{* * *}$ & $69.7 \pm 3.14^{* * *}$ & $85.4 \pm 2.35$ & $76.9 \pm 1.69^{*}$ \\
\hline & 84 & $41.8 \pm 2.04$ & $106 \pm 3.65^{* * *}$ & $75.9 \pm 1.77^{* * *}$ & $99.4 \pm 4.81$ & $89.9 \pm 1.42^{* *}$ \\
\hline \multirow[t]{2}{*}{ LDL (mg/dL) } & 0 & $15.7 \pm 2.59$ & $16.9 \pm 2.50$ & $16.8 \pm 2.34$ & $20.7 \pm 1.99$ & $20.3 \pm 2.91$ \\
\hline & 21 & $21.0 \pm 2.95$ & $54.9 \pm 6.23^{* *}$ & $30.4 \pm 1.68^{* *}$ & $63.7 \pm 2.64$ & $44.0 \pm 4.61$ \\
\hline \multirow[t]{5}{*}{ VLDL (mg/dL) } & 0 & $7.66 \pm 0.419$ & $8.00 \pm 0.470$ & $7.96 \pm 0.342$ & $8.41 \pm 0.337$ & $8.74 \pm 0.312$ \\
\hline & 21 & $8.02 \pm 0.419$ & $11.3 \pm 0.483^{\star * *}$ & $10.6 \pm 0.582$ & $12.3 \pm 0.465$ & $10.7 \pm 0.400$ \\
\hline & 42 & $8.21 \pm 0.419$ & $14.2 \pm 0.443^{\star * *}$ & $9.93 \pm 0.599^{* * *}$ & $15.1 \pm 0.524$ & $11.8 \pm 0.361^{*}$ \\
\hline & 63 & $8.13 \pm 0.366$ & $17.7 \pm 0.386^{* * *}$ & $13.9 \pm 0.629^{* * *}$ & $17.1 \pm 0.469$ & $15.4 \pm 0.337^{\star}$ \\
\hline & 84 & $8.36 \pm 0.409$ & $21.2 \pm 0.730^{* * *}$ & $15.2 \pm 0.355^{\star * *}$ & $19.9 \pm 0.956$ & $18.0 \pm 0.283^{* *}$ \\
\hline \multirow[t]{5}{*}{ HDL (mg/dL) } & 0 & $18.0 \pm 0.401$ & $17.9 \pm 0.522$ & $18.2 \pm 0.741$ & $17.9 \pm 0.463$ & $17.3 \pm 0.432$ \\
\hline & 21 & $18.8 \pm 0.233$ & $13.9 \pm 0.567^{* * *}$ & $17.3 \pm 0.476^{* * *}$ & $14.7 \pm 0.733$ & $15.5 \pm 0.446$ \\
\hline & 42 & $18.9 \pm 0.284$ & $13.2 \pm 0.700^{\star * *}$ & $17.1 \pm 0.547^{\star * *}$ & $12.2 \pm 0.683$ & $16.1 \pm 0.481^{*}$ \\
\hline & 63 & $19.6 \pm 0.408$ & $10.8 \pm 0.441^{* * *}$ & $18.3 \pm 0.436^{* * *}$ & $13.0 \pm 0.747$ & $14.7 \pm 0.849^{* *}$ \\
\hline & 84 & $19.4 \pm 0.423$ & $7.46 \pm 0.343^{\star * *}$ & $18.7 \pm 0.332^{\star * *}$ & $8.43 \pm 0.811$ & $10.9 \pm 0.586^{* *}$ \\
\hline
\end{tabular}

The data represented as mean \pm SEM for six rats, Values were considered significant when $p$ value less than 0.05 . Significant values were represented as follows such as ${ }^{*} p<0.05,{ }^{* *} p<0.01,{ }^{* * *} p<0.001$. Statistical values of all groups were compared with group II.

\section{Effect of butanol fraction on serum and tissue biochemical parameters}

Atherosclerosis markers from all groups of animals determined in serum (C-reactive protein and paraoxonase) and homogenate of aorta (myeloperoxidase and hydroxyproline) on $85^{\text {th }}$ day of protocol. Lipid emulsion has significantly $\left({ }^{* *} p<0.001\right)$ increased C-reactive protein, myeloperoxidase and hydroxyproline and decreased paraoxonase compared to animals received normal pellet diet. Lipid emulsion induced atherosclerosis markers significantly modulated by butanol fraction of Rivea ornata especially by upper dose $(400 \mathrm{mg} / \mathrm{kg})$. It decreases C-reactive protein $\left({ }^{* *} p<0.01\right)$, myeloperoxidase $\left({ }^{*} p<0.05\right)$ and hydroxyproline $\left({ }^{* *} p<0.01\right)$ and increases paraoxonase $\left({ }^{*} p<0.05\right)$ compared to lipid emulsion received animals. Vascular protective markers such as serum nitric oxide and aorta homogenate arginase and tissue thiols were determined at the end of $85^{\text {th }}$ day of study in all groups of animals. Lipid emulsion decreases significantly $\left({ }^{* \star} p<0.001\right)$ serum nitric oxide and aorta homogenate arginase and tissue thiols levels compared to normal pellet diet. But butanol fraction of Rivea ornata significantly increases the serum nitric oxide $\left({ }^{\star} p<0.05\right)$ and aorta homogenate arginase $\left({ }^{*} p<0.01\right)$ and tissue thiols $\left({ }^{* *} p<0.01\right)$ levels. Significantly $(P<0.001)$ decreased in the aorta tissue levels of catalase (CAT), superoxide dismutase (SOD), and reduced glutathione (GSH) and increased in the levels of Malondialdehyde (MDA) in lipid emulsion received animals compared to normal pellet diet received rats. Prior treatment with butanol fraction of Rivea ornata treatment for 84 days significantly $(400 \mathrm{mg} / \mathrm{kg})$ increased the levels of catalase $\left({ }^{\star *} P<0.01\right)$,
SOD $\left({ }^{* *} P<0.001\right), \mathrm{GSH}\left({ }^{*} P<0.05\right)$ and decrease the levels of MDA (* $P<0.05)$ in the aorta tissue compared with lipid emulsion received rats. Results are shown in Table 4.

The data represented as mean \pm SEM for six rats, Values were considered significant when $\mathrm{p}$ value less than 0.05 . Significant values were represented as follows such as ${ }^{\star} p<0.05,{ }^{* *} p<0.01,{ }^{* *} p<0.001$. Statistical values of all groups were compared with group II.

\section{Histopathology}

In normal pellet diet received aorta looking normal histoarchitecture. Lipid emulsion received rats observed with more foam cell in the tunica media and with damaged endothelium. Atorvastatin treated animals observed with less foam and intact endothelium. Butanol fraction at $200 \mathrm{mg} / \mathrm{kg}$ still observed with more foam cells. But at the dose of $400 \mathrm{mg} / \mathrm{kg}$ observed few very few foam cells and observed better protection. Histopathological changes are noted in Figure 3.

\section{DISCUSSION}

Hypercholesterolemia, inflammation and oxidative stress are the key factors involved in initiation and progression of atherosclerosis by endothelial dysfunction. Along with, reduction of availability of vasoprotective nitric oxide due to enhanced activity of arginase contribute some extent. ${ }^{25}$ So, complexity in etiology of atherosclerosis emphasis us to use such a drug which have multiple effects such as antihyperlipidemic effect, anti-inflammatory and antioxidant with arginase enzyme inhibition may have considered as potential way to prevent and control the 
Table 4: Effect of butanol fraction of Rivea ornata on serum and tissue parameters.

\begin{tabular}{|c|c|c|c|c|c|}
\hline Test group & 1 & II & III & IV & v \\
\hline $\mathrm{CRP}(\mathrm{mg} / \mathrm{L})$ & $1.80 \pm 0.19$ & $5.83 \pm 0.20^{* * *}$ & $3.15 \pm 0.34^{* * *}$ & $5.59 \pm 0.19$ & $4.30 \pm 0.42^{* *}$ \\
\hline Paraoxonase-1(U/mL) & $166 \pm 4.40$ & $107 \pm 6.44^{* * *}$ & $140 \pm 5.86^{* *}$ & $107 \pm 6.74$ & $133 \pm 2.71^{*}$ \\
\hline Myeloperoxidase(U/g) & $1.68 \pm 0.230$ & $6.60 \pm 0.225^{\star * *}$ & $2.60 \pm 0.215^{\star * *}$ & $6.31 \pm 0.441$ & $5.04 \pm 0.351^{\star}$ \\
\hline $\begin{array}{l}\text { Hydroxyproline } \\
\text { ( } \mu \mathrm{g} / \mathrm{mg} \text { protein) }\end{array}$ & $17.9 \pm 1.09$ & $57.3 \pm 2.06^{* * *}$ & $37.7 \pm 1.62^{* * *}$ & $45.7 \pm 3.66^{*}$ & $42.6 \pm 2.92^{\star *}$ \\
\hline $\begin{array}{l}\text { Nitric oxide } \\
(\mu \mathrm{mol} / \mathrm{L})\end{array}$ & $51.6 \pm 2.59$ & $13.7 \pm 3.30^{\star * \star}$ & $41.1 \pm 1.43^{* * *}$ & $14.9 \pm 4.34^{\mathrm{NS}}$ & $27.4 \pm 2.74 *$ \\
\hline $\begin{array}{c}\text { Arginase } \\
\text { (mg Urea/min/mg protein) }\end{array}$ & $0.27 \pm 0.05$ & $1.56 \pm 0.19^{* * *}$ & $0.56 \pm 0.03^{* * *}$ & $1.01 \pm 0.133^{*}$ & $0.93 \pm 0.07^{* *}$ \\
\hline Total thiol ( $\mu \mathrm{mol} / \mathrm{mg}$ protein) & $5.39 \pm 0.479$ & $2.22 \pm 0.208^{* * *}$ & $4.11 \pm 0.253^{\star *}$ & $3.72 \pm 0.363^{*}$ & $4.05 \pm 0.311^{* *}$ \\
\hline SOD & $135 \pm 3.96$ & $50.4 \pm 3.16^{* * *}$ & $104 \pm 4.68^{* * *}$ & $74.9 \pm 7.75^{*}$ & $85.7 \pm 5.27^{\star * *}$ \\
\hline CAT & $208 \pm 7.89$ & $116 \pm 2.82^{\star * *}$ & $175 \pm 5.30^{\star * *}$ & $128 \pm 6.42 \mathrm{~ns}$ & $152 \pm 5.41^{\star *}$ \\
\hline GSH & $72.1 \pm 3.61$ & $32.6 \pm 2.86^{* * *}$ & $61.6 \pm 2.71^{\star * *}$ & $41.1 \pm 2.96 \mathrm{~ns}$ & $46.3 \pm 2.15^{*}$ \\
\hline MDA & $37.4 \pm 4.49$ & $78.3 \pm 4.09^{* * *}$ & $49.2 \pm 2.25^{\star * *}$ & $64.6 \pm 2.07 \mathrm{~ns}$ & $62.1 \pm 3.14^{*}$ \\
\hline
\end{tabular}

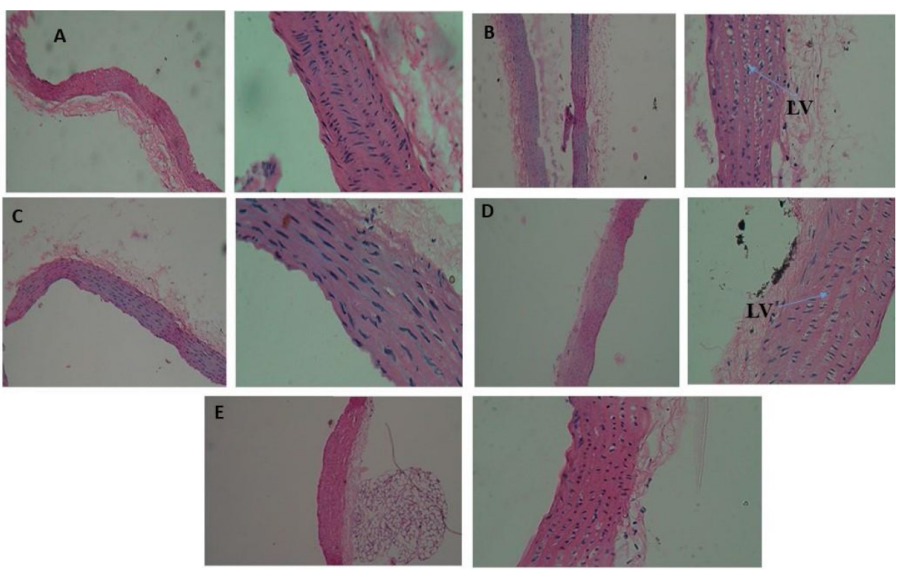

Figure 3: Histopathology sections of thoracic aorta: A. Normal rats; B. Lipid emulsion; C. Atorvastatin; D. Lower dose of Rivea ornata $(200 \mathrm{mg} / \mathrm{kg})$; E. Upper dose of Rivea ornata $(400 \mathrm{mg} / \mathrm{kg})$. LV= Lipid vacuoles.

atherosclerosis and associated ischemic heart diseases like angina pectoris and myocardial infraction would be treated much better than current therapy. It also reported earlier from various epidemiological and clinical trials. ${ }^{26}$ Based on the evidence we carry out the antiatherosclerotic effect of butanol fraction of Rivea ornata in lipid emulsion induced atherosclerosis in rat. Basically, polyphenols rich extracts have been proved with many pharmacological effects related to atherosclerosis. ${ }^{27}$ So, we extracted leaves of Rivea ornata with ethanol and latter fractionation were performed with solvents from nor polar to polar to get the polyphenol rich fraction. We found butanol extract was demonstrated positive for the polyphenols such as tannins, flavonoids and as well as observed with highest polyphenolic and flavonoid content than crude ethanol extract, other fractions including hexane, ethyl acetate and remining aqueous fractions. Butanol able to attract the polar polyphenolic substances from plant materials so it is considered as sources of bioactive polyphenolic rich extracts. ${ }^{28}$ Polyphenolic compounds are exhibit antoxidant activity by donating its hydroxyl groups to unstable free radicals, made it to stable that's why they protect the free radical induced oxidative stress, is known to common thing to cause LDL oxidation. LDL oxidation is the preliminary reaction before deposit in the vascular endothelium. ${ }^{29}$
Gallic acid is the major phenolic compound identified in the butanol extract by HPLC analysis based on matching of retention time of fraction and its standard gallic acid. ${ }^{30}$ For the in vivo atheroprotection activity we used lipid emulsion along with vitamin $\mathrm{D}$ to induce atherosclerosis in rats, as is most simple method with short time as well as to cause aorta calcification as like human atherosclerosis. Having obesity and hyperlipidaemia are known risk factors for atherosclerosis and these conditions were significantly established by administering the high fat lipid emulsion for the period of 12 weeks. ${ }^{31}$ Which were reflected as significant gain in the body weight and increase in the plasma levels of bad lipids such as TG, TC, LDL, VLDL and decrease in good lipids such as HDL compared to rats received balanced lipid containing pellet diet. Chronic administration of butanol fraction for 12 weeks exhibit dose dependently alleviate effect on the gain in the body weight and serum bad lipids such as TG, TC, LDL, VLDL and increase in good lipids such as HDL. This antihyperlipidemic effects of butanol fraction might be able to prevent the development of atherosclerosis. ${ }^{32}$ This effect also reflected on the atherogenic index, higher atherogenic index lower protection from atherosclerosis. Atherogenic index is the indicator of risk of coronary artery diseases. Antihyperlipidemic effect of butanol fraction is able to lower the atherogenic index and improved percentage protection from hyperlipemia induced cardiac risk dose dependently. ${ }^{33}$ Paraoxonase- 1 is an anti-inflammatory and antioxidant protein associated with HDL prevent the oxidative modification of LDL. Oxidized LDL deposited in the tunica medium and immediately recruited macrophages engulf this further form lipid loaded fatty plaques in the lumen of artery. Lipid emulsion administration cause significant decrease the atheroprotective paraoxonase-1due to which promote the oxidation of LDL and promote the endothelial inflammation. Butanol fraction dose dependently increases paraoxonase-1 level means is able to protect the oxidation of LDL. Inflammatory reaction associated with oxidized LDL promote the recruitment and activation of neutrophils release myeloperoxidase further propagates the oxidative damage in the vascular endothelium. We observed lipid emulsion induced vascular inflammation is indicated by significant increase in myeloperoxidase in serum of rat under hyperlipemia and it is decrease by butanol extract. ${ }^{34}$ Hypercholesterolemia associated with lipid emulsion causes endothelial dysfunction by impairment of eNOS function. eNOS is known for production of nitric oxide. Impairment of nitric oxide by enhanced activity of arginase which metabolize the nitric oxide percussor that 
is arginine. Hypercholesterolemia induced arginase activity impair the nitric oxide bioavailability due to which cause initiate the lipid deposition in the intima tunica. But butanol extract treated rat observed with inhibition of arginase by which it restores the nitric oxide levels and prevents the vascular plaques development and vascular stiffness. ${ }^{35}$ Hypercholesterolemia Vascular stiffness is the ultimate outcome of athresclerosis due to deposition of calcium and collagen synthesis. Excessive collagen synthesis is consequence of vascular inflammation by hypercholesterolemia. High hydroxyproline in the vascular tissue is the index of collagen deposition. Lipid emulsion causes high vascular hydroxyproline indicate promotion of vascular stiffness. ${ }^{36}$ Butanol fraction ameliorate the deposition of collagen dose dependently. Oxidative damage induced by hypercholesterolemia causes lipid peroxidation and oxidation of LDL. Both contribute to vascular damage. Antioxidant rich polyphenols containing butanol fraction significantly supresses the oxidative stress indicated by restoration of endogenous antioxidant such as catalase, superoxide dismutase, reduced glutathione and reduction of lipid peroxidation. Which indicate the antioxidant capacity of butanol fraction might have positive impact on oxidative damage of vascular tissue. ${ }^{37}$ Butanol fraction atheroprotection also observed in histopathology of rat aorta. Lipid emulsion administration promote the lipid deposition and wide gaps in the muscle layer. Whereas butanol fraction administration dose dependently antagonises the lipid disposition and gaps in the aorta. Which might be prevent the accumulation of fat in the vascular tissue by butanol fraction. ${ }^{38}$

\section{CONCLUSION}

By the observation of results of current study polyphenolic rich butanol fraction have antiatherosclerosis effect by balancing inflammation and oxidative stress by suppression of lipid emulsion induced inflammation markers and strengthen endogenous antioxidant system. Additionally, avail the availability of vasodilatory nitric oxide by inhibition of arginase helps further.

\section{ACKNOWLEDGEMENT}

Authors are thankful to the Principal, Correspondent for their constant support, encouragement and DST-FIST Facility of Raghavendra Institute of Pharmaceutical Education and Research, Anantapur, AP, India for the providing the proper facility to carry out this work.

\section{CONFLICT OF INTEREST}

The Authors Declare no conflict of interest.

\section{ABBREVIATIONS}

HPLC: High Performance Liquid Chromatography; WHO: World Health Organization; $\mathrm{Na}_{2} \mathbf{C O}_{3}$ : Sodium carbonate; $\mathbf{A l C l}_{3}$ : Aluminium chloride; NaOH: Sodium hydroxide DW: Distilled water; TLC: Thin Layer chromatography; $\mathbf{L D}_{50}$ : Lethal dose 50; ANOVA: Analysis of variance; $\mathbf{C a C l}_{2}$ : Calcium chloride; $\mathbf{M n C l}_{2}$ : Manganese chloride; $\mathbf{H}_{2} \mathbf{S O}_{4}$ : Sulfuric Acid; $\mathbf{H}_{3} \mathbf{P O}_{4}$ : Phosphoric acid; $\mathbf{H}_{2} \mathbf{O}$ : Water; OECD: Organisation for Economic Co-operation and Development; TPC: Total phenolic content; GAE: Gallic acid equivalent; TFC: Total flavonoid content; eNOS: Endothelial nitric oxide synthase.

\section{REFERENCES}

1. Diao SL, Sun JW, Ma BX, Li XM, Wang D. Influence of crocetin on high-cholestero diet induced atherosclerosis in rats via anti-oxidant activity together with inhibition of inflammatory response and p38 MAPK signaling pathway. Saudi J Biol Sci. 2018;25(3):493-9. doi: 10.1016/j.sjbs.2016.11.005, PMID 29692651.

2. Abrams J.. Clinical practice. Chronic stable angina. N Engl J Med 2005;352(24):2524-33. doi: 10.1056/NEJMcp042317, PMID 15958808.
3. Tan ST, Scott W, Panoulas V, Sehmi J, Zhang W, Scott J, et al, Elliott P, Chambers J, Kooner JS. Coronary heart disease in Indian Asians. Glob Cardiol Sci Pract. 2014;(1):13-23. doi: 10.5339/gcsp.2014.4, PMID 25054115.

4. Gao J, Liu C, Zhang H, Sun Z, Wang R. Myricitrin exhibits anti-atherosclerotic and anti-hyperlipidemic effects in diet-induced hypercholesterolemic rats. AMB Express. 2019:9(1):1-7:204. doi: 10.1186/s13568-019-0924-0, PMID 31865448.

5. Yang Z, Ming XF. Arginase: the emerging therapeutic target for vascular oxidative stress and inflammation. Front Immunol. 2013:4:149. doi: 10.3389/fimmu.2013. 00149, PMID 23781221.

6. Pernow J, Jung C. Arginase as a potential target in the treatment of cardiovascular disease: reversal of arginine steal?. Cardiovasc Res. 2013;98(3):334-43. doi: 10.1093/cvr/cvt036, PMID 23417041.

7. Minozzo BR, Fernandes D, Beltrame FL. Phenolic compounds as arginase inhibitors: new insights regarding endothelial dysfunction treatment. Planta mMedica. 2018;84(05):277-95. doi: 10.1055/s-0044-100398, PMID 29342480.

8. Kirtikar, K and Basu BD. Indian Mmedicinal Pplants - Volume III. Seco $2^{\text {nd }}$ Editioned,. Dehra Dun: linternational book distributors;2008.

9. Vaishali JS, Piyush MP. Bergenin-An active constituent of Rivea ornata Roxb. Aand its antioxidant property. Int J Pharmacogn. 2017;4(9):309-19.

10. Sholapur HN, Patil BM. Effect of Fractions of Alcoholic Extract of Moringa oleifera Lam. Bark on Ddexamethasone induced linsulin Resistance in Rats. J Young Pharm. 2017;9(3):410-6. doi: 10.5530/jyp.2017.9.81.

11. Baba SA, Malik SA. Determination of total phenolic and flavonoid content, antimicrobial and antioxidant activity of a root extract of Arisaema jacquemonti Blume. J Taibah Univ Sci. 2015;9(4):449-54. doi: 10.1016/j.jtusci.2014.11.001.

12. Siddiqui $R$, Ahamed HN, Yusuff I. bis flavonoids fraction from Araucaria bidwilli Hook., reverses hyperlipidemia induced atherosclerosis in high-fat diet induced hyperlipidemia., reverses hyperlipidemia induced atherosclerosis in high-fat diet induced hyperlipidemia. Futur J Pharm Sci. 2020;6(1):1-0.

13. Kaya B, Menemen Y, Saltan FZ. Flavonoid compounds identified in Alchemilla L. species collected in the North-eastern Black Sea region of Turkey. Afr J Tradit Complement Altern Med. 2012;9(3):418-25. doi: 10.4314/ajtcam.v9i3.18, PMID 23983376.

14. Konan KM, Mamyrbekova-Bekro JA, Bakalara N, Virieux D, Pirat JL, Bekro YA. HPLC analysis and cytotoxicity of n-butanol extract from Glyphaea brevis roots against c6 glioma cells. Sci Pharm. 20132014;82(1):171-6. doi: 10.3797/ scipharm.1307-08, PMID 24634849

15. Maithili V, Dhanabal SP, Mahendran S, Vadivelan R.. Antidiabetic activity of ethanolic extract of tubers of Dioscorea alata in alloxan induced diabetic rats. Indian $J$ Pharmacol. 2011;43(4):455-9. doi: 10.4103/0253-7613.83121, PMID 21845005.

16. Gou SH, Liu BJ, Han XF, Wang L, Zhong C, Liang S, et al, Liu H, Qiang Y, Zhang Y, $\mathrm{Ni}$ JM. Anti-atherosclerotic effect of Fermentum Rubrum and Gynostemma pentaphyllum mixture in high-fat emulsion- and vitamin D3-induced atherosclerotic rats. J Chin Med Assoc. 2018;81(5):398-408. doi: 10.1016/j. jcma.2017.08.018, PMID 29107606.

17. Subramani C, Rajakkannu A, Rathinam A, Gaidhani S, Raju I, Kartar Singh DV. Anti-atherosclerotic activity of root bark of Premna integrifolia Linn. in high fat diet induced atherosclerosis model rats. J Pharm Anal. 2017;7(2):123-8. doi: 10.1016/j.jpha.2016.12.002, PMID 29404027.

18. Mehdi MM, Rizvi SI. Plasma protein hydroperoxides during aging in humans: correlation with paraoxonase 1 (PON1) arylesterase activity and plasma tota thiols. Arch Med Res. 2013:44(2):136-41. doi: 10.1016/j.arcmed.2013.01.003, PMID 23376056.

19. Arya DS, Arora S, Malik S, Nepal S, Kumari S, Ojha S. Effect of Piper betle on cardiac function, marker enzymes, and oxidative stress in isoproterenolinduced cardiotoxicity in rats. Toxicol Mech Methods. 2010;20(9):564-71. doi: 10.3109/15376516.2010.514962, PMID 20846025

20. Hedayati M, Niazmand S, Hosseini M, Baghcheghi Y, Beheshti F, Niazmand MJS Vitamin E improved redox homeostasis in heart and aorta of hypothyroid rats. Endocr Regul. 2017;51(4):205-212. doi: 10.1515/enr-2017-0021, PMID 29232192.

21. Akinyemi AJ, Onyebueke N, Faboya OA, Onikanni SA, Fadaka A, Olayide I. Curcumin inhibits adenosine deaminase and arginase activities in cadmiuminduced renal toxicity in rat kidney. J Food Drug Anal. 2017;25(2):438-46. doi: 10.1016/j.jfda.2016.06.004, PMID 28911688

22. Boyapally R, Pulivendala G, Bale S, Godugu C. Niclosamide alleviates pulmonary fibrosis in vitro and in vivo by attenuation of epithelial-to-mesenchymal transition, matrix proteins \&Wnt/ $\beta$-catenin signaling: A drug repurposing study. Life Sci. 2019; 220:8-20. doi: 10.1016/j.Ifs.2018.12.061, PMID 30611787.

23. Thippeswamy BS, Mahendran S, Biradar MI, Raj P, Srivastava K, Badami S et al, Veerapur VP. Protective effect of embelin against acetic acid induced ulcerative colitis in rats. Eur J Pharmacol. 2011;654(1):100-5. doi: 10.1016/j. ejphar.2010.12.012, PMID 21185828

24. Bale S, Sunkoju M, Reddy SS, Swamy V, Godugu C.. Oropharyngeal aspiration of bleomycin: Aan alternative experimental model of pulmonary fibrosis developed in Swiss mice. Indian J Pharmacol. 2016;48(6):643-648. doi: 10.4103/02537613.194859, PMID 28066100.

25. Davignon J, Ganz P.. Role of endothelial dysfunction in atherosclerosis Circulation. 2004;109(23);Suppl 1(23_suppl_1): III27-32. doi: 10.1161/01. CIR.0000131515.03336.f8, PMID 15198963. 
26. Zhang X, Ye B.. Isolation of Pprunin Ffrom Bauhinia variegata and lits Aantioxidant Aactivity in Rrats Fed an Atherogenic Diet. Nat Prod Commun. 2020;15(10):1934578:X20967875. PMID 1934578.

27. Huseini HF, Anvari MS, Rabbani S, Sharifi F, Arzaghi SM, Fakhrzadeh H. Huseini HF, et al. Anti-hyperlipidemic and anti-atherosclerotic effects of Pinus eldarica Medw. nut in hypercholesterolemic rabbits. Daru. 2015;23(1):32. doi: 10.1186/ s40199-015-0114-9, PMID 26054525.

28. Akowuah GA, Sadikun A, Mariam AJ. Flavonoid identification and hypoglycaemic studies of the butanol fraction from Gynura procumbens. Pharm Biol. 2002;40(6):405-10. doi: 10.1076/phbi.40.6.405.8440.

29. Sirichaiwetchakoon K, Lowe GM, Eumkeb G. The Ffree Rradical Sscavenging and Aanti-lisolated Hhuman LDL Ooxidation Aactivities of Pluchea indica (L.) Less. Tea Ccompared to Ggreen Ttea (Camellia sinensis). BiomMed Res Int. 2020;2020:4183643. doi: 10.1155/2020/4183643, PMID 33029506

30. Mahboob T, Nawaz M, de Lourdes Pereira M, Tian-Chye T, Samudi C, Sekaran SD, et al, Wiart C, Nissapatorn V. PLGA nanoparticles loaded with Ggallic acid-a constituent of Leea indica against Acanthamoeba triangularis. [Ssci Rrep.:20208954]. Sci Rep. 2020;10(1):1-2:8954. doi: 10.1038/s41598-02065728-0, PMID 32488154

31. Wu Y, Wang Y, Liu X, Jiang L, Guli A, Sailike J, et al, Sun X, Abuduwaili N, Tuoliuhan H, Maney K, Nabi X. Ziziphora clinopodioides flavonoids based on network pharmacology attenuates atherosclerosis in rats induced by high-fat emulsion combined with vitamin D3 by down-regulating VEGF/AKT/NF-kB signaling pathway. Biomed Pharmacother. 2020;129:110399:110399. doi: 10.1016/j. biopha.2020.110399.

32. Zhu X, Zhang W, Pang X, Wang J, Zhao J, Qu W. Hypolipidemic Effect of
n-Bbutanol Extract from Asparagus officinalis L. in Mice fed a High-fat Diet. Phytother Res. 2011;25(8):1119-24. doi: 10.1002/ptr.3380, PMID 21280112.

33. Balzan S, Hernandes A, Reichert CL, Donaduzzi C, Pires VA, JuniorGasparotto AG, et al, Cardozo EL. Lipid-lowering effects of standardized extracts of Ilex paraguariensis in high-fat-diet rats. Fitoterapia. 2013; 86:115-22. doi: 10.1016/j.fitote.2013.02.008, PMID 23422228.

34. Huang Y, Wu Z, Riwanto M, Gao S, Levison BS, Gu X, et al, Fu X, Wagner MA Besler C, Gerstenecker G, Zhang R, Li XM, DiDonato AJ, Gogonea V, Tang WH, Smith JD, Plow EF, Fox PL, Shih DM, Lusis AJ, Fisher EA, DiDonato JA Landmesser U, Hazen SL. Myeloperoxidase, paraoxonase-1, and HDL form a functional ternary complex. J Clin Invest. 2013;123(9):3815-28. doi: 10.1172/ JCI67478, PMID 23908111.

35. Harisa GI, Attia SM, Zoheir KM, Alanazi FK. Chitosan treatment abrogates hypercholesterolemia-induced erythrocyte's arginase activation. Saudi Pharm J. 2017;25(1):120-7. doi: 10.1016/j.jsps.2016.05.007, PMID 28223872.

36. Lü L, Zhang D, Sun B, Hu Y, Yan M, Liu K, et al, Li X, Ren L. Apocynum leaf extract inhibits the progress of atherosclerosis in rats via the AMPK/mTOR pathway. Pharmazie. 2017;72(1):41-8. doi: 10.1691/ph.2017.6703, PMID 29441896.

37. Sarma $R$, Kumari $S$, Elancheran $R$, Deori $M$, Devi $R$. Polyphenol rich extract of Garcinia pedunculata fruit attenuates the hyperlipidemia induced by high fat diet. Front Pharmacol. 2016.;7:294. doi: 10.3389/fphar.2016.00294, PMID 27642282.

38. Kilany OE, Abdelrazek HMA, AldayelTS, Abdo S, Mahmoud MMA. Anti-obesity potential of Moringa olifera seed extract and lycopene on high fat diet induced obesity in male Ssprauge Dawely rats. Saudi J Biol Sci. 2020;27(10):2733-46. doi: 10.1016/j.sjbs.2020.06.026, PMID 32994733.

Article History: Submission Date : 12-05-2021; Revised Date : 27-05-2021; Acceptance Date : 18-06-2021.

Cite this article: Jyothi MV, Devanna N, Sudheer A. Arginase Enzyme Inhibition and with Subsequent Atheroprotection of Butanol Fraction of Rivea ornata in Lipid Emulsion Induced Atherosclerosis in Rats. J Young Pharm. 2021;11(2):176-83. 